\title{
Symbiotic Learning Systems: Reorganizing and Integrating Learning Efforts and Responsibilities Between Higher Educational Institutions (HEIs) and Work Places
}

\author{
Olav Eikeland
}

Received: 4 October 2012 / Accepted: 15 October 2012 /

Published online: 10 November 2012

(C) The Author(s) 2012. This article is published with open access at Springerlink.com

\begin{abstract}
This article presents the idea of "symbiotic learning systems" as a possible strategy for dealing with institutional knowledge and learning challenges posed by an emerging transition from "socially monopolized" to "socially distributed" knowledge generation and distribution. As knowledge production and learning become increasingly relocated from segregated and specialized institutions for research and education and socially distributed to and within "ordinary" work life, corresponding changes are required in the basic institutionalized relationships between research, higher education, and practical knowledge application. The concept of "symbiotic learning" addresses these problems by deconstructing age-old divisions between vocational and liberal education. In order to build foundations for a changed and improved relationship between advanced organizations in work life and institutions of higher education and research (HEIs), the general preconditions for learning in the work places themselves need to be addressed. In modeling general preconditions for learning, and even in transcending the division of labor between manual and intellectual work, inspiration is found in the philosophy of Plato and Aristotle, and in their search for intellectual "commons" (tà koiná) as constituting public spheres and community among individuals.
\end{abstract}

Keywords Symbiotic learning system · Organizational learning · Action research Public spheres · Counter public spheres $\cdot$ Commons

The following text presents the idea of "symbiotic learning systems." This idea has grown through several attempts to deal with institutional knowledge and learning challenges posed over the last half-century at least, on a societal level, by an emerging transition from "socially monopolized" to "socially distributed" knowledge

O. Eikeland $(\bowtie)$

Faculty of Education, Oslo and Akershus University College of Applied Sciences, St. Olavs plass, P.O. Box 4, 0130 Oslo, Norway

e-mail: olav.eikeland@hioa.no

URL: www.hioa.no 
generation and distribution (Gibbons et al. 1994; Nowotny et al. 2001; Eikeland 1999a, b). The emerging "new knowledge management regime" or "new mode of knowledge production" is characterized by increased global competition and technological change, increasingly knowledge based and competence intensive work life, new ICT and social media, highly educated workers at all levels, highly educated, informed, and critical users/customers/consumers, and increasing requirements in both private and public enterprises for continuous learning, research, improvement, development, and innovation. Both private and public organizations, at all levels, become increasingly populated by highly educated individuals. Simultaneously, advanced work life is often more "up-to-date" than educational institutions concerning technological and organizational solutions.

It has been evident for some time that these new constellations challenge inherited hierarchical models of organization (like scientific management and bureaucracy), which are mostly based on a division of labor between thinking and planning in the higher organizational echelons, and mere execution of systemically predefined tasks by more or less unskilled labor on "the floor" of organizations. By challenging conventional conceptions of who learns what, how, when, and where, they also challenge traditional educational institutions. Simultaneously, from a different angle, challenges requiring similar solutions concerning validity and the relationship between theory and practice or theory and experience come from an epistemological and methodological perspective. ${ }^{1}$ In industry and business, the possibilities are explored of refining and upgrading practically and experientially acquired knowledge, tacit knowledge etc. as the basis for insight and understanding and for practical measures and innovations (cf. Nonaka and Takeuchi 1995), raising questions about who should (most appropriately) research what, where, how, when, and why. The new regime is gradually (and still, in spite of financial and debt crises) changing the institutional relations between research, education, and work life (Winter and Maisch 1996; Slaughter and Leslie 1997; Teare et al. 1998; Symes and McIntyre 2000; Levin and Greenwood 2000, 2001; Jarvis 2001; Slaughter and Rhoades 2004; Barnett 2006; McNay 2006; Levin and Greenwood 2008; Greenwood 2012). ${ }^{2}$

The challenges posed by these developments are comprehensive and fundamental. They concern much more than the conventional and simple tug of war between "scientific rigour" and "practical relevance" among different but apparently unchanged social interests, organizations, and institutions. The increasing dispersion of competence, knowledge production, and learning through society and work life requires the transformation of research, higher education, and practical knowledge application, making all three continuously less "ordinary." The institutional and individual division of labor between intellectual and manual work is at stake.

Before proceeding, I will briefly explain the term "symbiotic," introduced in working papers (Eikeland 2005, 2006) in order to describe the proposed model of collaboration between learning organizations in work life and HEIs providing

\footnotetext{
${ }^{1}$ Cf. Eikeland 1985, 1995, 1997, 2008a, 2009. The reflexive methodology of Alvesson and Sköldberg (2000) incorporates most of the recent discussions in the philosophy of social research. Still, they seem to remain within the confines and divisions of labor of interpretive or qualitative social research, and do not see the radical institutional implications.

${ }^{2}$ Symbiotic learning systems may be seen as a version of what Levin (2004) calls "cross-boundary learning systems," but where the boundaries themselves move and change.
} 
education for professions. The term symbiosis is Greek. It may generate associations to biology and psychology. But here, the word bios or biôsis is used in a "prebiological" and "pre-psychological" sense. "Bíos," (and even more so, "bíosis") in Greek, originally did not primarily designate abstract "natural life" as such, common to all living things, as in the modern discipline of biology. Rather, it meant "lifestyle" or "way of living" as in "bios theoretikós" and "bios praktikós" in Aristotle. " A biological symbiosis is by definition mutually beneficial, which, transferred to this case, would mean, on the one hand, that symbiotic learning does not threaten academic freedom or academic standards, on the other hand that it will contribute to the improvement of individual and collective practice in organizations. Hence, symbiosis is used to mean some form of entangled or interwoven relationship and new modus vivendi from which all partners involved - those active in learning, research, and performance - will benefit. Hence, I conclude that "symbiotic learning" is an appropriate term for what is arguably needed between work life and institutions providing education for the professions (i.e., the field of vocational education and training [VET] expanded to include research based professions and semi-professions more generally). ${ }^{4}$

The basic aim of what follows is to suggest some general preconditions for individual and organizational learning in both academic and less academic work places, and to describe how this learning, in turn, is required for an improved collaborative and institutional integration of work, learning and knowledge generation, education, and innovation, making these relations more "symbiotic." 5 Theoretically, the general learning preconditions sought for have been developed from explicitly philosophical sources in Plato and Aristotle and "the philosophical" biôsis extracted from their texts. ${ }^{6}$ When work place learning as systematic organizational and individual self-evaluation is achieved, it can be used both for educational purposes and for solving immediate problems and challenges and improving individual and collective practice. It can articulate tacit knowledge and competence and disclose different perspectives and common realities, and finally, it can define emergent and long-term learning challenges and research questions without being limited to a search for what is instrumentally useful merely for immediate application or acute problem solving. Instead of reducing work-based or practice-based learning to problem or project based learning (PBL), symbiotic learning reinstates apprenticeship learning in a modernized version as its core.

In practical terms, a central challenge is how to optimize and accredit the use of a presumed systematized method of learning and research in the work places as a basis

\footnotetext{
${ }_{3}^{3}$ Ancient philosophy in itself was a way of life; a bísisis, as emphasized especially by Hadot (1995). See Eikeland 1997, 2008a.

${ }^{4}$ The point is not, of course, that "everything" should "always" be learned while working on the shop floor of some work life enterprise. The point is even less that everyone should only learn as much as is needed for shop floor practice or only as much as needed for solving some particular niche problem or challenge. University education cannot be reduced to conventional VET. The general point is rather that conceptual understanding is and must be developed as experience formation, in close conjunction between relevant practice and reflection. The general educational and learning model may be seen as a form of modernized apprenticeship learning model.

${ }^{5} \mathrm{Cf}$. the call from CEDEFOP (2011) for an integration of training/education, work based learning/learning organizations, and innovation.

${ }^{6}$ For detailed references to the texts of Plato and Artistotle cf. Eikeland (1997), (2008a).
} 
for providing formal professional education by the institutions of higher education, and for the benefit of both work places and academic learning. In order for learning in the work place to serve this function (and not remain subordinate to external research as it mostly is, for example, in the "evidence based" movement), it cannot remain unrecorded, and merely informal and serendipitous. It has to become more systematic and testable. The focus in what follows is on explaining the logic and organization of this type of learning. For reasons of space, what is required from HEIs in order to enter into a symbiotic collaboration with the kind of work life relevant for their students is presented more sketchily and in outline.

\section{Beyond the Linear Transfer Models of Modernism}

Inherited conventional and linear models of learning, research, knowledge transfer, application, and innovation (cf. Stokes 1997) would seem to presuppose that

1) Research which produces general theories is primarily done in institutions separate from and extraneous to the objects studied, and separate, extraneous, and prior to practice/performance/application.

2) Knowledge is transmitted, embodied, and embedded primarily didactically and theoretically through positive teaching and through explicit design and instruction.

3) People are finished with education in their youth and merely work afterwards.

4) Learning is conceived as the appropriation of knowledge produced by others (preferably researchers, at least research based and "evidence based").

5) Practice is conceived as the application of knowledge, techniques, inventions, innovations, precepts, and rules made by others (preferably researchers, research and "evidence based").

6) Organizations are similar to machines (or organisms) where all parts and members (as cog-wheels or organs) perform their niche tasks and where all unoccupied leisure is seen as unproductive "slack" and time wasted.

These are modernist ideas, and to a large extent, the institutions of modernity (increasingly since the revolution of natural science in the seventeenth century) have been both based and shaped on more or less implicit or explicit assumptions like these in their divisions of labor and ideas about learning and knowledge transmission or diffusion. These ideas have probably never been quite true. But at least within the emerging socially distributed knowledge management regime (some would say "postmodernist regime"), research is no longer done merely in separate research institutions, knowledge and competence is not merely based on and generated through extraneous research, knowledge is no longer merely transmitted through teaching, and competent practical performance is not (and probably never was) merely the application of separately and externally produced theories or rules. Individual lifelong learning is needed and encouraged, learning is increasingly practice-based, organizations need to learn and change continuously, learning and knowledge transfer happen through widespread networks and ICT, and thinking, reflecting, planning, and controlling are required at all levels in an organization. As a consequence, old ways of coordinating collective practices and work are challenged. 
Also, as a cumulative consequence of these long-term societal changes, work based learning and organizational learning and research must be upgraded at all levels. When we realize that knowledge and competence are as much (or even primarily) generated in the context of practice, performance, and enactment, not outside, before, or after, the very idea that knowledge should (and actually must) first be produced by externally based researchers and institutions and then transmitted afterwards by equally external educational institutions in order finally to be applied by so-called practitioners (by following precepts, formal instructions, or orders), cannot remain unchallenged. ${ }^{7}$ Concerning the education of professionals, the temporary internship (or so-called practicum) as a limited part of basic education constitutes a too weak link between education and work, and, at the same time, it is too poorly organized with regard to learning. ${ }^{8}$

Triple Helixes and Collaboration Between Business and Research

As a response to some of these changes, there are many ongoing discussions about collaboration between research and business, and many efforts at closing the gap between academia and external practical contexts. But recent innovation theories about triple helix alliances between HEIs, government, and industry (cf. for example, Etzkowitz 2008), and similar theories tend to focus more on research than on education and learning, and, at the same time, they seem mostly to focus on relations between these parties more or less as they are currently constituted; thus, their relations are envisaged in terms of the commercialization of research ideas through their transformation into products and entrepreneurship. The more or less implicit starting point and model for these theories is natural science and technology. Linear innovation and diffusion models may be appropriate in areas where specialized researchers are true pioneers at frontiers never before visited by human beings and where specialized technology is needed (typically micro- and macro-cosmic fields of exploration and exploitation). Using the same models for areas where researchers normally are the last to arrive (as in all kinds of social research) is considerably more problematic. In addition, most educations for professions (lawyers, psychologists, teachers, social workers, nurses, etc.) are not directly concerned with the inner workings of nature and technology. In their professional practice, they relate to nature and technology mostly as users. In different ways, professional practice concerns relations between people and relates more to the social sciences and humanities as basic disciplines. Yet if and when triple helix approaches and models are transferred to the mostly non-technological professions, they seem to retain a linear model of innovation and diffusion, where knowledge is produced by external research methods and researchers.

Slightly differently, however, from the emphasis in most of the literature on innovation and collaboration between universities, business, and government, the reconfiguration of collaboration needed concerns the basis, form, and content of learning, development work, and formal education as much as it concerns specialist

\footnotetext{
${ }^{7}$ Cf. Dreyfus and Dreyfus (1986) on strict rule-following as the lowest stage in their ladder of competence.

${ }^{8}$ The practicum is a historical reminiscence from an earlier, more widespread and more broadly conceived apprenticeship model of learning.
} 
research where results are "transferred" and "implemented" afterwards. Although symbiotic learning is not completely incompatible with linear transfer and technical innovation models, their integration is not merely a question of simple combination. It is rather a question of fusion and transformation needing philosophical and methodological attention, as the reconfiguration concerns ways of knowing (gnoseology) and research methodology. ${ }^{9}$

Symbiotic learning systems must be based on trying to produce, develop, and improve social and professional knowledge as explications of ways of doing things from within professional and organizational practices. They must utilize organizational learning and learning through professional practice, also for academic purposes. Hence, without diminishing the emphasis on research, the idea of a "symbiosis" between work based learning and the graduation system in higher education starts with the way work places are either organized or disorganized with respect to conditions for learning; the way work place organizations either promote or deter systematic, critical, self-evaluative, practice-based learning. By rethinking and integrating both education and research into organizational and work based learning, some of the mismatch and transmission costs can be lowered between academia and work. Immediate relevance and "applicability" is a constant concern of work life, and academic freedom, standards, and values are the concerns of HEIs. If sufficient care is taken, a closer integration does not necessarily endanger any of these. On the contrary, symbiotic learning systems will probably be better both concerning the relevance and implementation of learning and knowledge, and when it comes to generating conceptual understanding and theoretical insight, if not in every field, at least in professional practice, organizational knowledge, and social science. ${ }^{10}$

\section{The Third Task or Mission of HEIs}

In terms of the tasks of HEIs, symbiotic learning addresses how their two major tasks or missions of (a) providing higher education and (b) doing research, might be reconfigured in light of HEIs' so-called "third task" of (c) collaborating with external partners in regional and work-place developments and innovations, and in the light of (d) the consequences of an increased general need and capacity for continuous learning and innovation in business and work life.

Norwegian and Scandinavian universities and university colleges are legally obliged to perform this third task or mission alongside the tasks of education and research. Approaches towards this third task of HEIs are divided between those employing a broad and those employing a more narrow understanding of the task. The broad understanding includes a basic reconsideration of institutional relations and new infrastructure to handle the changing relations between work life, education, and research. The narrower approach has a more limited focus on certain aspects of the third task through the transfer of knowledge and commercialization of ideas

\footnotetext{
${ }^{9}$ Cf. Eikeland (2007; 2008a)

${ }^{10}$ This conclusion is based on critical reviews of broadly recognized and accepted methodological shortcomings and philosophical challenges inherent in conventional social research. Cf. for example, Eikeland $(1985 ; 1995 ; 2009)$.
} 
springing from the activity of researchers ending with concrete product innovations and entrepreneurship. Although there is no necessary contradiction or opposition between these, the narrow approach is based mainly on a linear transfer model. Basically, it takes the conventional institutional framework with its division of labor between research, education, and application for granted. But the third task consists in more than the commercialization and transfer of knowledge produced in universities. The linear and technical model of transfer and commercialization of knowledge has received more attention because it does not question conventional research methods, ways of knowing and learning, and the conventional organization of the relations between research, learning, and practical performance. It is apparently easier to handle administratively. But it thereby also presupposes certain models of knowledge and knowledge generation not generally suitable for all fields. Finne and Hubak (2004:iii-iv), however, conclude their report for the Norwegian Research Council by emphasizing that neither an older linear transfer model nor a conventional commissioned research model will be able to solve the challenges raised by new requirements for collaboration between research institutions and work life aiming at innovation. Both of these models are based on a division of labor and on transfer of knowledge either by conventional teaching and education, by popularization, or by commercialization. However, it is precisely the presumed division of labor or dualism between thinking and performing, knowledge generation and application, producing and receiving knowledge, which needs to be problematized. ${ }^{11}$ Finne and Hubak call for ways of "getting to grips with firms and for developing arenas and overlapping networks and communities of practice that are able to contribute to developing both research institutions and firms mutually." New infrastructure must be established in order to promote a mutual learning relationship between research, education, and practice, which stimulates both research and learning, and innovative products and practices in all camps. A more comprehensive, fused or symbiotic model is needed where changes in one (research, education, or third task) entails changes in the others. These tasks already overlap. At the masters and $\mathrm{PhD}$ level, research and education overlap, and research methods need to be addressed critically and reflectively. At the bachelor level, the training of professionals needs to be practice based to a greater degree.

\section{A Model for Organizational Learning}

The basic idea of a symbiotic learning system is to systematically utilize for formal educational purposes what must become systematic and organized efforts in work places to pursue critical and self-evaluative individual and organizational learning. This means not merely recognizing competence gained from any informal learning, or from individual projects. It means systematizing and organizing work based and organizational learning, primarily for developing improvements in work places, but also as a basis for gaining formal educational credits. As emphasized by Darling-

\footnotetext{
${ }^{11}$ The connections pointed out by CEDEFOP (2011) between training, organizational learning, and innovation, need to be fully taken into account, thereby broadening the scope of the third mission considerably.
} 
Hammond (2006a:309), learning from practice in work places which are badly organized for solving primary tasks, and not geared for learning, may be directly counterproductive. It will teach us neither improved practice nor improved theory and understanding. Whole work places need to be geared for individual and collective learning.

In this context, the term "organizational learning" is used to designate a special form or way of learning, slightly differently from how others use similar terms. ${ }^{12}$ There are important differences between (a) "learning in organizations," (b) "learning organizations," and (c) "organizational learning." Learning in organizations comprises all sorts of learning going on in certain places or systems called organizations or work places. The conscious and formalized part of this is often called "training," an attempt at bringing people to a predetermined standard of skill or knowledge, often by sending them out of the workplace or organization for a period of time as well, taking courses in colleges and universities. In organizations or work places, there may be learning going on through the use of questionnaires and surveys among employees or customers as well, and certainly there is a lot of informal individual learning going on within the organization, for example when new employees have to adjust to the local culture and informal authority structures. But organizational learning is not just the sum total of all the different kinds of learning being engaged in by all the individuals in the organization, added together. It is something different, both more and less.

Neither is organizational learning the same as a "learning organization." A learning organization is a unit that learns, the way a machine, a human individual, an animal, and other units may learn. ${ }^{13}$ Units may learn in different ways. A learning organization may, for example, learn by means of a given and traditional organizational structure, as when a CEO or someone else hears about some new technique, gadget, or "device" which the organization then gets hold of, trains the employees to use, and then implements to perform new and old tasks in better ways. In this way the organization as a presumed unchanged unit has learned to use the new device. But this is still not organizational learning, although it could imply organizational learning as a consequence of introducing new gadgets.

Organizational learning is neither a specific place for learning nor is it a certain unit that learns. It is a way or form of learning. In projects over the last 20 years, we have tried to distinguish between four different forms of learning, without pretending to exhaust all possibilities or aspects of learning through these simple divisions (cf. Eikeland and Berg 1997; Eikeland 2012). Along one dimension we distinguish between individual and collective learning. Along another we distinguish between theoretical learning and what we might call experiential-experimental or practical learning. Organizational learning is characterized by being collective and experiential-experimental; experience-based. Theoretical learning in this division means mainly learning by listening or reading. New terminology and new concepts appropriated through reading or listening may of course create new perspectives, new "maps" that make new options visible, and contribute to the reinterpretation and reorganization of existing experience. But this kind of learning in itself hardly

\footnotetext{
12 See for example Easterby-Smith et al. (1999) and Easterby-Smith and Lyles (2003)

13 Talking about "organizations" as units that learn is useful and meaningful as an abbreviation. It does not imply any specific commitment or opinion about the ontological status of organizations, however.
} 
changes the learners' basic ability to do things; to perform. Practice, exercise, and habituation are usually necessary for the development of new skills and abilities to do things and for the formation of new experience.

Furthermore, we can practice alone or we can practice together. When practicing together we can either practice in parallel without interacting at all (as in a training studio), or we can practice in common, trying to improve our ability to perform some task together or solve a common problem or challenge. This mutual adjustment to each other in trying to identify and develop collective "best practices" is organizational learning in this terminology, since this implies actually changing the relations between individuals - their division of labor, their communication patterns, their leadership and authority structures, in one word: their "organization" if you likein order to improve collective performance. In organizational learning, the whole organizational unit transforms internally. This cannot be done without individual skill development and learning of course, but it is still something different and something more than the development of individual skills in parallel and the sum of these simply added together. It is also more than merely "team learning" since relations between organizational levels and departments may be changed.

The basic process is obvious in football or in music and dancing where a group of individual virtuosos and soloists still doesn't make a winning team or orchestra or dance ensemble. The difference, change, and progress from starting out as a crowd of more or less talented individuals gradually becoming an amateur football team, orchestra, or ensemble and later on a professional team, in a way is organizational learning. A number of people assembled, transforming their relationships from the crowd's inability to perform a certain complex task, through "team stages" from novice to expert or virtuoso performance of the same or more complicated tasks, developing and changing their relations and mutual practices on the way, is a form of organizational learning.

When talking about the organization of their work place, most people talk about their work organization as something that organizes the performance of the primary tasks of the organization, the reason it exists; the production of things, services, knowledge or whatever. The work organization consists of the division of labor and relations of superiority and subordination between departments, levels, and individuals in the organization ("flat" or "steep"). In addition to organizing tasks of a semipermanent character lasting for years and repeated continuously, most work places create short term "project organizations"- "task forces"-in order to deal with unique and short term tasks. Project organizations are often created by people from several departments or disciplines and terminated when their assignments are done. For some organizations, like the shipbuilding industry, most of their work is organized as large projects, and even health and social workers are increasingly forming interdisciplinary teams surrounding clients where the restitution of each and every client's physical, psychic, and social health becomes a project.

It is not unusual to think of development work as well, whether organizational, professional or of other kinds, in terms of projects, and correctly so for many development tasks. But when organizations are increasingly forced into a mode of "continuous improvement" in all fields in order to survive, developmental and learning tasks no longer stay temporary. They become permanent, and move from the periphery to the center. This creates tasks that are permanent, but still different 
from and on a "meta-level" in relation to the mere performance of the primary tasks in predetermined ways. For the general preconditions for practical learning and improvement need to be addressed.

This is one reason why some of us since the second half of the 1980s (cf. Eikeland 2012) have been thinking in terms of permanently organized development work or learning activities, and baptized this meta-organization "development organization" in order to distinguish it from both work organizations and temporary task forces/ project organizations. Developing and improving people's abilities, work organizations, professional competence, product quality, work environment, power relations, ways of communicating, etc. are specific tasks demanding ways of relating, communicating, and organizing which are different from when simply performing according to given standards within these dimensions. A critically self-evaluative, learning mode is needed.

The model for organizational learning used in projects since 1990 is explained in Eikeland and Berg (1997) and Eikeland (2012), its theoretical or philosophical base in Eikeland (1997; 2008a). The model presents how to conceptualize and systematize an alternation between action and reflection for all employees or more metaphorically between performing or playing roles "on stage," and stepping out of roles in a space for dialogical reflection "back stage," examining and changing roles critically. Improvement and perfection develop through this process of alternation. Organizational learning, then, means changing any aspect of the work organization by means of a "meta-organization" in order to improve performance.

The space "back stage" constitutes a dialogue-based counter public sphere internal to the organization. In comparison with performing on stage, the back stage is a "free space," "open space," or forum for non-competitive but critical conversation or dialogue - a counter-public sphere-where collaboration in clarifying mutual and common understanding, and learning to do things better together-developing collective, team and organization competence - is important, not winning an argument.

\section{Historical and Philosophical Bases}

It is worth some reflection that the original Greek word skholê; the basis for "school" as the place for learning par excellence in almost all European languages, simply means just this: a free and open space-leisure, a break-from necessary work and labor. This fact has been fundamental to the development of the approach presented here, and has been explicitly developed from some basic Aristotelian distinctions. ${ }^{14}$ Space restrictions do not allow for more than merely mentioning three concepts central to the approach: (a) skholê, (b) dialogue, and (c) deliberative phrónêsis. As indicated, the word skhole, or "school," means leisure, or otium in Latin. Among the ancient philosophers, this skhole was designed specifically for reflection. Originally, skholê was not like a didactic didaskaleion as the Greeks used to call what we today think of as a school. Reflection was more important than undergoing instruction or

\footnotetext{
${ }^{14}$ My studies of ancient philosophy and Aristotle especially, and my work with organizational learning and action research have been simultaneous and interactive activities since the first half of the 1980s (cf. Eikeland 1997, 1998, Eikeland 2006, 2008a).
} 
teaching, at least among those following the practice of Socrates who claimed not to teach anything to anyone.

The second concept-dialogue-most people associate with Socrates and Plato more than with Aristotle. But it was central to Aristotle's thought also (Eikeland 1997, 2008a). Dialogue, or dialectics, was the inductive way of inquiring, finding, researching, discovering, and defining; of guidance, moving "upwards" or "inwards" from the "first-impressions" and fumbling of novices and how things immediately appear to us, to the general skills and insights of an expert-i.e., virtue - based on a better grasp of how things are in themselves. Dialogue was conceived by Aristotle as complementary to the deductive way "downwards" or "outwards" of presenting knowledge, and to the didactic or instructive exposition by a teacher of a finished body of knowledge. Didactic teaching has received a historically embedded and institutionalized social space and a fixed position in the lecture halls and classrooms of educational systems. But the practically embedded reflective space for dialogue - the original skhole — has had a much more precarious existence and has never received a similar social institutionalization. Building organizational learning is one way of providing it.

The third concept, deliberative phrónêsis, has experienced a widespread revival lately. But it has been appropriated too much in isolation from and in opposition to theoretical reason and interests (cf. Eikeland 1985, 2006, 2008a). Although in understanding and enacting the social world we may not need much spectatorbased "astronomical" theory as the external study of others - not even the interpretive kind provided by qualitative social research — we need a different kind of theory. ${ }^{15}$ Dialogue was originally directed by a theoretical interest in developing general insight and competence from extracting and explicating patterns (general ways of doing things) found in the practically acquired experience of the actor-knowers themselves. Deliberative phrónêsis was openly directed at finding and generating contextually adjusted appropriate action based on this kind of dialogically developed "grammatical" or "methodological" insights, while persuasive rhetoric was directed at winning support from others for specific, mostly predetermined purposes and conclusions.

The three concepts mentioned (skholê, dialogue, phrónêsis) provide general or common preconditions for learning and for perfecting practices individually and collectively. They were part of what Aristotle talked about as the communityconstituting intellectual commons or tà koiná (cf. Eikeland 2008a: 299-454). Modern firms, organizations, communities, and societies need professionalism as the perfection of practices more than ever. Aristotle considered sufficient leisurethe reflective space of skhole - a necessary precondition for developing and realizing virtue or excellence in any field, and for participating in affairs common to group members, i.e., in politics. Without this reflective space, work (or any activity) would degenerate into mere repetitious toil and drudgery, unable to improve and raise itself to free, autonomous, and independent virtue or excellence. Along with skhole, critical dialogue or dialectics was necessary for developing general skills and insights

\footnotetext{
${ }^{15}$ Cf. Eikeland and Nicolini (2011). See Eikeland (2008a and 2009) on different Aristotelian ways of knowing, and the possibility and necessity of developing a praxis-based theory of common forms where the separation between knower and known is suspended.
} 
through training and guidance. And the ultimate objective of Aristotelian politics was supporting and promoting practical virtue in everyone everywhere as far as possible. Lastly, phrónêsis as a specific kind of virtuous deliberation interpreting the current situation and enlisting and weighing arguments pro et contra (i.e., not merely deductions, calculations, or "practical syllogisms"), in order to find the best way practically in the present situation, was considered necessary for perfecting a complex practice during performance by adjusting optimally to the circumstances.

Both dialogue and phrónêsis need reflective spaces relieved from acute busyness; dialogue even more so than deliberation. Dialogue especially cannot be reduced to "negotiation" whose original meaning is simply "business talk" or actually busyness talk, bartering and trading under time and power pressures for reaching some agreement or deal on some compromise or action. The Latin nec-otium literally means no-leisure, and a negotiator was a "no-leisured" businessman. For professionalism, for virtue and mastery, for developing insight, for autonomy, independence and freedom, all the three concepts-leisure, dialogue, and deliberation-are needed (Eikeland 2008a). Hence, they need to be introduced and implanted even in modern work life in order for it to be able to provide the professionalism increasingly required by modern users, customers, and work life organizations.

Dialogue and deliberative phrónêsis - as part of the intellectual commons or koiná - constitute the core of what has been called "meta-tasks" earlier, situated in an organized, leisured free space or skhole in a social "back stage," and needed as general preconditions for individual and organizational learning and for perfecting practices individually and collectively, alternating between reflective leisure (back stage) and performative activity (on stage). With Aristotle they represent a reflective dome of both theoretical and practical wisdom - both sophía and phrónêsis-overarching every work-organized substantial task (no matter how menial and humble) to be developed and cultivated to its appropriate virtue or excellence. Their organizational embedding and implementation require a fundamental revision of the often tacit machine-like assumptions about organizational (and societal) effectiveness and of organizational members performing as parts of machines, where every slot of leisure and spare time is considered a waste. Aristotle actually argued in favor of a social distribution of these preconditions among all citizens, against Plato's elite having a privileged access to dialogue as their exclusive "niche expertise." 16 But skhole, dialogue, and deliberation are not complementary niche privileges, powers, tasks, or competences. They are general and common to all who are able; and necessary for each and every one in order to prevent any work, task, or activity from degenerating into the drudgery of heteronomous and undignified toil. Nussbaum's opposition and defense of so-called "liberal education" (1997:297-298) against "vocational education" serves to illustrate the contemporary relevance of the distinctions. Her context appears to be an inherited opposition between universities of the classical German kind (Humboldt; liberal) and technical colleges as they were conceived after the French Revolution (vocational). But similar oppositions have longer ancestries going back to differences between Plato and Aristotle.

\footnotetext{
${ }^{16}$ Discussing Aristotle's exclusion of so-called "natural slaves," manual laborers, women, and strangers from full citizenship is important and interesting. Still, it stops us too quickly from seeing the relevance of the relations he required among the citizens themselves. Cf. Eikeland (2008a: 493-501) for a discussion.
} 
Among Aristotle's critiques of Plato was that Plato conflated the qualitative difference between a large household (oikos) and the community of citizens in a city state (pólis). The professional skill of the household was oikonomía or economy, while the skills of citizenship were politics (derived from "what concerns citizens" or politai $=$ politikê $)$. Plato and Socrates reduced the difference to quantity alone, making a small political community identical to a large household and thereby reducing the pólis to the organizational principles of the household. For Aristotle, however, a political community was based on freedom and equality among the citizens, while the household was an organizational totality dealing with necessary chores based on a strict division of labor between niche tasks. For Aristotle, but not for Plato, the basic difference between politics and economy concerned their principles of coordination or organization. In principle, a household was kept together and organized by the head of the house (despótês) and his closest subordinate managers thinking, planning, coordinating, ordering, and controlling - by force if necessarythat tasks were done according to the specifications and the needs of the totality. At every level, subordinates were to follow the will of their superiors. Ways of knowing such as poíêsis (producing, manipulating, creating), khrêsis (using), pathos (passively receiving and suffering) and theôrêsis (extraneous observation and hypothetical conjecture) belong to and describe household relations. ${ }^{17}$

In a political community, however, action is coordinated by people sharing knowledge, understanding, and insights. This means that thinking, planning, coordination, and control must be carried out among peers in an open community agreeing on basic ways of doing things (homónoia, or concord) and where everyone knows each other's roles and tasks within a totality which everyone also understands and shares publicly; where roles and tasks can be examined, redefined, and rotated among the members. The basic principles of political coordination are equality, freedom, sharing, community, open dialogue and deliberation, and transparency. Ways of knowing like praxis (doing, activity) and theôría (insight) belong to and characterize political relations between free and equal individuals.

Although Aristotle considered the political to be the only ethical and dignified relationship, he realized that not everyone could be literally equal in every way. Some form of division of labor is necessary. Hence, the practical establishment of equal, political relations of citizenship was and remains a challenge. And throughout most of European history, Plato's idea of the state or politics as a large household has dominated both theory and practice. It has legitimized authoritarian and patriarchal organizational forms. By differentiating clearly between private and public, modernity and modern democracies are much more Aristotelian in this sense, however, at least in theory (cf. Eikeland 2008b).

This difference between pólis and oikos is likewise the partly subconscious and only vaguely articulated historical backdrop for the opposition between Nussbaum's "liberal" and "vocational" education. Vocational education is seen as a unilateral adjustment to Plato's niche competencies within totalities based on complementary divisions of labor, while "liberal education" was and is seen as being for those who were and are liberated from this "vocational predicament" and were able to dedicate

${ }^{17}$ Cf. Eikeland (2008a) for a detailed discussion of different ways of knowing and forms of knowledge in Aristotle. 
their almost unlimited leisure or free time to activities they enjoyed; music, art, literature, and other "useless," i.e., not immediately applicable, or rather productive, studies, but also to politics. Liberal education (the artes liberales) was literally for free citizens (liberales), not for the unfree. The opposition goes back to a conception of work and leisure which undoubtedly has its roots in a certain reading of Aristotle. According to this conception, work was toil and labor with necessary chores, totally without leisure or skhole. Leisure or skholê was free from necessary labor or work and contained only such activities as "totally free" individuals liberated from necessary work could dedicate their time to, voluntarily. The opposition between "liberal" and "vocational" education repeats an ancient division of labor where vocational practice was "illiberal" and unfree. The question is if and how such an opposition still has any validity or legitimacy.

Aristotle can be read differently, for example, in light of Plato's conception of leisure or skhole in his dialogues Theaitetus and the Laws. According to this reading, the point is not to be totally liberated and separated from practical tasks, but rather to be free from a constant and immediate pressure to act from natural or authoritarian necessity. One's spare time-leisure - is not conceived as being totally external to and separated from practical work as in the former interpretation, nor is leisure the privilege of a minority only. Manual work was not inferior or degrading, not even to Aristotle. It usually became inferior and degrading because of the heteronomous relations and conditions (of force and necessity) under which it was normally done; enforced, on command (from nature or authority) and dominated by external forces. In this interpretation, leisure-skhole - must provide a space among the practitioners themselves for reflection and rehearsal, without any thought about certain decisions or actions that need to be taken or carried out immediately, and without external "lords" leaning over you. Instead, insight, understanding, competence, and improved practice - learning and virtue (arête) — constituted the "scholastic" aim, rather than finding solutions to problems needing solutions immediately or within specific deadlines. This skhole constitutes the space for open, free, and critical dialogue or dialectics; and Plato presents this with explicit reference to how colleagues and masters and apprentices in a craft talk about improving their practice, in contrast to rhetoric and didactics, but also in contrast to deliberation in action about what to do the next instant.

If we stick with this reading, the result is not a deep split and division between individuals who have their time filled with the degrading drudgery of necessary chores done under constant time pressure and other external forces, and individuals who only reflect, think, and plan or can dedicate themselves totally to free activities. Working individuals also need the space for reflection - the skhole or leisure-in order to perform their work in a good way (through phrónêsis) and constantly improve it (through dialogue). The best standard is not fulltime leisure and reflection. Even those who think need some kind of performance or activity to think through!

This means that competent and virtuous "vocational functioning" presupposes an environment characterized by openness through dialogue and deliberation. Excellence cannot be simply an execution of thoughts, plans, coordination, and control made by others. It cannot merely be narrowly niche-specialized in its performance. This goes - a fortiori-for cases where excellence in "vocational functioning" is collective, as it normally is in advanced, modern work organizations. This 
necessity of dialogue and openness is something independent craftsmen and artists have always understood and realized since antiquity. But it has not really had any significant impact, either practically or theoretically, on household organization and coordination, or in modern work organizations. But this is really the essence of what Aristotle conveys when he emphasizes that skhole or leisure is necessary to develop any activity from the mere drudgery of execution to real virtue or excellence.

If the relationship between work and skhole is interpreted in this way, the separation and opposition is deconstructed between an education for the leisurely activities of the already free (liberales), on the one hand, and a vocational education for "functionaries" merely adjusted to a complementary niche function within a total societal division of labor, on the other. It would signal the end of talking about either school-learning or learning through work or practice. School learning (skholê) was not originally purely instructive and demonstrative. It was not theoretical teaching of a positively given body of knowledge separate from practice. ${ }^{18}$ The original leisure or skholê was inserted and integrated into practical contexts as a dialogical or dialectical space for critical reflection and conversation, and as a general precondition for good practice or performance. Hence, insisting on the limited "functionality" of vocational competencies perpetuates an out-dated view of vocations as "illiberal" and belonging to an oikos organization.

According to Aristotle 2,350 years ago, the more equal people become concerning virtue (knowledge, competence, ethical and political excellence), the less well monarchy, hierarchy, and external authority function as coordinating mechanisms. Today, people talk about knowledge societies, new knowledge management regimes, socially distributed knowledge production, etc. and people are actually becoming increasingly equal in many respects. The whole inherited, split relationship between work and learning is changing. The immediate relevance of Plato and Aristotle was for me the theoretical pretext for the distinction employed since 1987, between "work organization" and "development organization" (cf. Eikeland 1987; Eikeland and Berg 1997; Eikeland 2012). The complementary, niche-labor-divided totality, within which "vocational competence" has normally been defined as functional, is the work organization, still having a mostly oikos-similar structure. In the work-organization you are "on-stage" playing your ascribed roles. But being work-organized "on-stage" is not all there is to being human, not even at work (although modern work organizations try to eliminate all organizational slack). In the semi-leisured development organization you move "back stage" for openly discussing and criticizing roles, tasks, cooperation, division of labor, management and leadership etc. in order to improve collectively at collaborating and solving problems "on stage." The possibility of changing and exchanging roles and tasks is presupposed. The purpose is the learning that happens in the alternation between skhole and performance. Creating back stage fora for dialogical reflection in the work place means quite literally creating "schools" integrated within practical contexts. In the back stage investigation of the activities and relationships "on stage," the participants are really equal (in that they are all doing the same things, the same tasks), no matter what role they usually play "on stage." In the common,

\footnotetext{
${ }^{18}$ Although modern Greek has succumbed to the use of the now common word school or skholeion for all primary training, you can still find places (like the north-west of Lesbos) where the older, more modest, and more correct "didaskaleion" is used to designate a modern school.
} 
critical, and dialogical activity, every participant is principally and practically a peer. Hence, the political and ethical community in an organized division of labor is secured through the meta-organization of the intellectual commons or koiná.

To create learning systems within the work place means, then, to create a permanent system that gives everyone the opportunity to alternate between the work organization on stage and the development organization back stage in order to learn and to improve their practice. This could mean systematizing the use of meeting places or fora already present in the work place, or creating new ones for collective and individual reflection on work experiences. The use of dialogue conferences and workshops, search conferences, future workshops, change laboratories, open space technologies etc. are ways of operationalizing a back stage forum or development organization. The challenge is to find permanent ways of integrating and institutionalizing these back stage fora for reflection in the work place by scrutinizing and analyzing the extant formal and informal meeting places at work in order to use them more consciously for learning purposes.

\section{Old and New Challenges}

Thinking in terms of organized development work and organizational learning as an alternation between being on stage performing and back stage reflecting opens for an expanded way of working with "learning by doing." Ordinary problem- and project based learning (PBL) and problem solving, as these activities are often described, rely to a large extent on existing sources of knowledge and expertise and on the effective utilization of existing information. Practice, exercise, experimentation and reflection, however, try to develop expertise, insights, virtuosity as "peak" competence and performance. Slightly exaggerated, we could say that PBL and problem solving is here-and-now oriented in a utilitarian way and promotes a horizontal mode of learning while an expanded understanding of practice-based learning promotes a vertical mode of learning as in apprenticeship learning. PBL is most appropriately suited to the needs of the restricted functionality of the old vocationalism.

Even though there does not have to be any contradiction or opposition between these two ways of thinking about learning through practice and experience, thinking in terms of switching between "on stage" and "back stage" is better suited to those forms of learning that are practically based, but not simply based on solving acute problems or participating in projects. This way of thinking also allows us to think of knowledge generation and research more generally, not as the privilege of spectators in the audience "off stage," but as situated in the middle of - within-different practices, alternating between "on-stage" performative experience and "back-stage" reflection and analysis. As I have elaborated elsewhere (cf. Eikeland 1997, 2008a, 2009), this way of working can produce "theory" in the good sense of articulate insight and understanding as well.

On this basis, then, a number of insufficiencies in widespread ways of thinking about the relationships between work and academia can be superseded. Only a few will be briefly mentioned here, however:

1. The old tug-of-war between "relevance and rigor" can be reformulated and surpassed. Educational institutions often think of internships, problem based 
learning, project work etc. as educational wedges into work life, merely as limited measures for bringing students through to their individual exams. Work places often want to reduce higher education to what is immediately relevant for the everyday running of business and problem-solving. Symbiotic learning systems allow both higher education and professional work places to think more holistically and less unilaterally and instrumentally about the other.

2. Symbiotic learning makes it possible to reinstate a modernized, full scope apprenticeship learning (individual and collective), i.e., not merely PBL and project based learning - as the model for practice-based learning at the core of work based learning.

3. Symbiotic learning surpasses limitations in the way normal customized studies are organized as further education. Customized studies normally utilize PBL and project work, but often do not effectuate intended changes in work-places requiring collective, organizational learning.

4. Symbiotic learning makes it easier to secure academic career advancement through professional practice and prevent the establishment of an academic elite within the education of professions, lacking practical-professional experience. ${ }^{19}$

\section{Towards Symbiosis: Rudiments}

Clearly, a learning system which is symbiotic between work and formal education provides challenges for both work places and educational institutions. In order to construct a learning system that is able to handle the many challenges in relation to learning, education, research, development, knowledge application, and innovation, firms and enterprises must take on the responsibility of working systematically with their collective and individual learning, organizing both as activities in the work place. All the competence of critically interpretive and reflexive research methodology is needed here. Educational institutions need to rethink where, how, when, and in what order people learn and to reorganize their educational offers and research work in close collaboration with the "receivers" of their finished professional candidates, making the necessary adjustments, for example, by allowing for and requiring whole enterprises to sign up for certain studies and by rethinking the order and contents of curriculum requirements. An alternation between learning in work places organized for learning, and school learning both didactic and reflective, must be organized. When symbiotic collaboration is established the symbiosis can be utilized for systematic learning and research both by the worker-collective and by individuals taking their exams in educational institutions at bachelor, master, or doctoral levels. The exchange of personnel would increase naturally as working professionals base their masters and $\mathrm{PhD}$ work on combined work-based and school based learning, and start teaching novices to the profession. The symbiosis creates new communities of learning and inquiry across old institutional and organizational borders, and creates challenging encounters between different ways of knowing, as documented in Darling-Hammond (2006b). As indicated, there is no need to reduce what is learned or researched to what is narrowly and instrumentally useful for immediate problem solving. Rather, the key challenge is to use practical challenges in order to expand

$\overline{19}$ These and other aspects will be dealt with in a separate article. 
critically, learn "vertically," and stretch freely "upwards" and "inwards" in understanding based on internal academic criteria and acknowledged research frontiers.

Since a fully fledged symbiotic learning system must be based on a close collaboration between work life and education, it will probably require some form of negotiated and binding social contract between work life and educational institutions. Norway may be ripe for such a contract, based on the strongly organized structure and relationships and the generally collaborative climate and culture in Norwegian work life. Similar contracts already established concerning enterprise development, lifelong learning, accreditation of informal and non-formal learning and competence acquisition, work-based VET apprenticeships, mandatory MBO in public services, a work environment act requiring organizations to provide the preconditions and opportunities for learning, the existence of educational hospitals and nursing homes and corporate $\mathrm{PhDs}$ in private and public enterprises, make Norwegian work life prepared for such a step.

A model course for the introduction of symbiotic learning was developed and important experiences were gained in a pilot organizational learning project in the Norwegian municipality of Arendal during the years 2000-2004 (Eikeland 2001; Eikeland et al. 2002), organized as a university course in organizational learning. Employees from four different departments participated. A second round was run in the psychiatric division of a central hospital in Norway during 2007 and 2008 with the following objectives:

- To train the ability for improved collective learning/task solution in the work place.

- To combine work practices with the organization of learning in the work place and with formally accredited education.

- To exploit the practically based learning in the work place as a basis for the development of formal competence.

- To build new relations between work places and educational institutions as part of a symbiotic learning system.

The model has been further developed with schools and used in an educational master's course at the former Akershus University College (now Oslo and Akershus University College) between 2009 and 2011.

Many interventions by consultants and action researchers are deficient in making permanent changes in work organization, work culture, etc. They are often too focused on specific problem-solving but lack a more general and systematic practical approach to learning and the organization of learning. The starting point for building symbiotic learning systems is to secure the general preconditions for individual and collective learning in the work place, involving all employees. But this would also create an environment in which

1) Students in basic vocational and professional training and education would be better taken care of in the work place as apprentices in their internship or practicum periods, since learning is systematized among all employees.

2) An increased and improved use of practice-learning and practical work experience could take place in master and $\mathrm{PhD}$ studies by employees.

3) Learning relationships to "users" (for example, parents), suppliers, collaborators, and other stakeholders could be established. 
4) A greater "absorptive capacity" (Cohen and Levinthal 1990), that is, openness for and ability to utilize knowledge and innovations from other sources, conventional R\&D, etc. could be developed.

These courses, which are supposed to support the construction of a learning system, are based on project work in the work place as in most ordinary customized courses, but with the big difference that although only some individuals participate as students, all employees and whole departments participate with the establishment of a learning system as their common project. Through these basic educational courses in organizational learning, building the preconditions for symbiotic learning, the participants are supposed to:

- Acquire skills and competence in collective learning and competence development in the work place.

- Acquire competence in systematic knowledge generation based on experience from organizational practice, work, and professional performance.

- Acquire insight and competence in questions concerning research methods and theoretical knowledge connected to relevant forms of knowledge generation and learning.

- Acquire understanding and insight in societal developments forming the background for the increased need for strengthening learning and competence development in the work place.

- Be able to work as facilitators for practice based learning activities in other divisions than their own.

\section{Summary}

In order to improve the education of professions, organizational and professional practice, and research in organizations and professional practice, the development of a much closer and symbiotic learning relationship between higher education and work life is needed. A social contract between higher education and work places for professions is needed where the work places have to build their capacity for organizational learning as the foundation. This article has tried to explain some aspects of the background to this claim, the logic of organizational learning, and how the institutional reform needed can find theoretical support in ancient philosophical sources.

Open Access This article is distributed under the terms of the Creative Commons Attribution License which permits any use, distribution, and reproduction in any medium, provided the original author(s) and the source are credited.

\section{References}

Alvesson, M., \& Sköldberg, K. (2000). Reflexive Methodology - New Vistas for Qualitative Research. London: Sage Publications.

Barnett, R. (Ed.). (2006). Reshaping the University—new relationships between research, scholarship, and teaching. Philadelphia: The Society for Research into Higher Education \& Open University Press. 
CEDEFOP. (2011). Learning while working-success stories on workplace learning in Europe. Luxembourg: Publications Office of the European Union.

Cohen, W. M., \& Levinthal, D. A. (1990). Absorptive capacity: a new perspective on learning and innovation. Administrative Science Quarterly, 35(1), 128-152.

Darling-Hammond, L. (2006a). Constructing 21st-century teacher education. Journal of Teacher Education, 57(3), 300-314.

Darling-Hammond, L. (Ed.). (2006b). Professional development schools-schools for developing a profession. NYC: Teacher's College Press.

Dreyfus, H., \& Dreyfus, S. (1986). Mind over machine. The power of human intuition and expertice in the Era of the computer. New York: Free Press.

Easterby-Smith, M., \& Lyles, M. A. (2003). Handbook of organizational learning and knowledge management. Oxford: Blackwell Publishing.

Easterby-Smith, M., Burgoyne, J., \& Araujo, L. (1999). Organizational learning and the learning organization - developments in theory and practice. London: Sage Publications.

Eikeland, O. (1985). H.W.Smith og jakten på den skjulte mening eller: the actual meaning of triangulation, s.173-208 i Østerberg, Dag \& Otnes, Per (red.): Sosiologisk Årbok, 1985. Oslo: Institutt for Sosiologi, UiO.

Eikeland, O. (1987). Rapport til Hovedavtalens bedriftsutviklingstiltak (HABUT); Bilbransjeprosjektet, AFI-notat 31/87. Oslo: Arbeidsforskningsinstituttet.

Eikeland, O. (1995). Aksjonsforskningens horisonter-et forsøk på å se lenger enn til sin egen nesetipp, s.211-268 i Eikeland, Olav \& Finsrud, Henrik Dons (red.) (1995): Research in Action — Forskning og handling — søkelys på aksjonsforskning. Oslo: AFIs skriftserie nr.1, Arbeidsforskningsinstituttet.

Eikeland, O. (1997). Erfaring, dialogikk og politikk—Den antikke dialogfilosofiens betydning for rekonstruksjonen av moderne empirisk samfunnsvitenskap. Et begrepshistorisk og filosofisk bidrag, 3.utgave. Oslo: Universitetsforlaget.

Eikeland, O. (1998). Anamnesis - dialogisk erindringsarbeid som empirisk forskningsmetode, s.95-136 i Eikeland, O. \& Fossestøl, K. (red.) (1998): Kunnskapsproduksjon i endring - nye erfarings- og organisasjonsformer.Oslo: AFIs skriftserie nr.4, Arbeidsforskningsinstituttet.

Eikeland, O. (1999a). From training to learning — new trends and future perspectives, AFI-notat 3/99. Oslo: Work Research Institute.

Eikeland, O. (1999b). Mot et nytt kunnskapsforvaltningsregime?, AFI-notat 7/99. Oslo: Work Reseach Institute.

Eikeland, O. (2005). Symbiotisk laringssystem, Project Description to the Norwegian Research Council from the University College in Oslo (ENNY), dated August 31st 2005.

Eikeland, O. (2006). Symbiotisk laringssystem, Project description to the Norwegian Research Council program VIOS (verdiskapende innovasjon i offentlig sektor), from the Work Research Institute, dated August 30th, 2006.

Eikeland, O. (2008a). The ways of aristotle - aristotelian phrónêsis, aristotelian philosophy of dialogue, and action research. Bern: Peter Lang Publishers.

Eikeland, O. (2008b). Beyond the Oikos-Pólis divide? Historical transformations of the private-public relationship, and current work life developments. In A. M. Berg \& O. Eikeland (Eds.), Action research and organization theory (pp. 23-60). Frankfurt a.M.: Peter Lang Publishers.

Eikeland, O. (2009). "Habitus-validity in organisational theory and research—social research and work life transformed", chapter 1. In B. Brøgger \& O. Eikeland (Eds.), Turning to practice with action research (pp. 33-66). Frankfurt a.M.: Peter Lang Publishers.

Eikeland, O. (2012). Action research and organisational learning - a norwegian approach to doing action research in complex organisations. Educational Action Research Journal, 20(2), 267-290.

Eikeland, O., \& Berg, A. M. (1997). Medvirkningsbasert organisasjonslaring og utviklingsarbeid i kommunene. Oslo: Kommuneforlaget.

Eikeland, O., \& Nicolini, D. (2011). Turning practically_broadening the horizon, Introduction to the special issue of journal of organizational change management. Journal of Organizational Change Management, 24(2), 164-174.

Eikeland, O. (2001). Challenges for organizational learning and competence development in a Norwegian municipality, Paper presented Mini-biennale, Akershus University College, 4-7 april, 2001.

Eikeland, O. (2007). From Epistemology to Gnoseology—Understanding the Knowledge Claims of Action Research, pp. 344-358 in Management Research News, Volume 30, No. 5, special issue on International Perspectives on Validity and Epistemology in Action Research.

Eikeland, O., \& Klemsdal, L.(2002). Studie-/fagplan for organisasjonslæring i Arendal kommune, Godkjent 10-vekttalls studieplan ved Høgskolen i Agder/Filonova, AFI, Oslo, juli \& november, 2002. 
Etzkowitz, H. (2008). The triple helix-university-industry-government, innovation in action. New York: Routledge.

Finne, H., \& Hubak, M. (2004). Nye Arbeidsformer for MOBI? Om kompetansebruk $i$ bedrifter og samhandling mellom forskning og bedrift. Trondheim: Sintef \& Norges Forskningsråd.

Gibbons, M., et al. (1994). The new production of knowledge-the dynamics of science and research in contemporary societies. London: Sage Publications.

Greenwood, D. (2012). Doing and learning action research in the neo-liberal world of contemporary higher education. Action Research, 10(2), 115-132.

Hadot, P. (1995). Philosophy as a way of life. Oxford: Blackwell Publishing.

Jarvis, P. (2001). Universities and corporate universities. London: Kogan Page Ltd.

Levin, M. (2004). Cross-boundary learning systems - integrating universities, corporations, and governmental intitutions in knowledge generating systems. Systemic Practice and Action Research, 17(3), $151-159$

Levin, M., \& Greenwood, D. (2000). Reconstructing the relationships between universities and society through action research. Handbook of Qualitative Research.

Levin, M., \& Greenwood, D. (2001). Pragmatic Action Research and the Struggle to Transform Universities into Learning Communities. Handbook of Action Research.

Levin, M., \& Greenwood, D. (2008). The future of universities: action research and the transformation of higher education, the sage handbook of action research. London: Sage Publications.

McNay, I. (Ed.). (2006). Beyond mass higher education - building on experience. Philadelphia: The Society for Research into Higher Education \& Open University Press.

Nonaka, I., \& Takeuchi, H. (1995). The knowledge-creating company-how japanese companies create the dynamics of innovation. New York: Oxford University Press.

Nowotny, H., et al. (2001). Re-thinking science-knowledge and the public in an age of uncertainty. Cambridge: Polity Press.

Nussbaum, M. (1997). Cultivating humanity-a classical defense of reform in liberal education. Cambridge: Harvard University Press.

Slaughter, S., \& Leslie, L. L. (1997). Academic capitalism-politics, policies, and the entrepreneurial university. Baltimore: The Johns Hopkins University Press.

Slaughter, S., \& Rhoades, G. (2004). Academic capitalism and the new economy-markets, state, and higher education. Baltimore: The Johns Hopkins University Press.

Stokes, D. E. (1997). Pasteur's quadrant-basic science and technological innovation. Washington D.C.: Brookings Institution Press.

Symes, C., \& McIntyre, J. (2000). Working knowledge-the new vocationalism and higher education. Philadelphia: The Society for Research into Higher Education \& Open University Press.

Teare, R., Davies, D., \& Sandelands, E. (1998). The Virtual University - An Action Paradigm and Process for Workplace Learning. London: Cassell.

Winter, R., \& Maisch, M. (1996). Professional Competence and Higher Education: The ASSET Programme. London: The Falmer Press. 